\title{
PENERAPAN MESIN PENGADUK YOGHURT SEBAGAI UPAYA PENINGKATAN PRODUKSI
}

\section{APPLICATION OF YOGURT STIRRER MACHINE AS A EFFORTS FOR INCREASING PRODUCTION}

\author{
${ }^{1)}$ Riski Nur Istiqomah Dinnullah, ${ }^{2}$ Shafiq Nurdin \\ ${ }^{1)}$ Universitas Kanjuruhan Malang, ${ }^{2}$ Poltek Unisma Malang \\ email: ky2_zahra@unikama.ac.id
}

\begin{abstract}
ABSTRAK
Selain memiliki manfaat yang lengkap sebagai minuman kesehatan, yoghurt memiliki harga yang terjangkau dan telah banyak dikonsumsi oleh masyarakat.Banyak industri rumahan yang mulai tertarik untuk menjadikan yoghurt sebagai salah satu usaha alternatif.Beberapa UKM produksi yoghurt ini adalah UKM Yoghurt Yovita dan UKM Yoghurt Yosh yang menjadi mitra pada program ini.Pada kedua UKM tersebut masalah yang muncul adalah terbatasnya penggunaan mixer standar dalam proses pengadukan yoghurt sehingga menyebabkan kurang maksimalnya kuantitas produk yoghurt yang dihasilkan. Selanjutnya, tujuan dari program ini adalah menyelesaikan masalah produksi tersebut dengan dibuatkannya mesin pengaduk yoghurt otomatis dengan kapasitas yang lebih besar.Tahapan kegiatan pada program ini meliputi proses desain mesin, persiapan bahan dan alat, pelaksanaan workshop dan pendampingan pengoperasian dan perawatan mesin pengaduk yoghurt. Dari hasil kegiatan yang telah dilaksanakan terlihat bahwa mitra sangat antusias dalam mengikuti program tersebut.Hal ini dapat diketahui dari banyaknya peserta yang mengikuti kegiatan dari awal hingga akhir dilaksanakannya program.Mitra juga lebih terampil dalam mengoperasikan mesin dengan didampingi oleh Tim Pelaksana Program. Melalui kegiatan ini, diharapkan kedepannya akan mampu membantu meningkatkan perekonomian dan kesejahteraan bagi para pemilik UKM tersebut.
\end{abstract}

Kata Kunci: UKM, Yoghurt, Mesin Pengaduk

\begin{abstract}
Yoghurt is a health drink that has a complete benefit. It also has an affordable price and has been widely consumed by the community. Many home industries are getting interested to make yoghurt as one alternative business. Two partners in this program are UKM Yoghurt Yovita dan UKM Yoghurt Yosh. The UKM's problem is a standart mixer used in the production process causes the quantity of the resulting product is not optimal. It can not meet the number of consumer demand. The purpose of this program is to solve the production problem by creating an automatic yoghurt stirrer machine with a larger capacity. Stages of program's activities include the process of machine design, preparation of materials and tools, the implementation of workshops and mentoring of the operation and maintenance of yoghurt stirring machines. The results show that partners are very enthusiastic in following the program. It can be seen from the number of participants who follow the program from the beginning until the end of the activities. This program can also add partner's skills in operating the machine. In the future, it is hoped that this program will be able to help improve the economy and prosperity for the owners of UKM.
\end{abstract}

Keyword: UKM, Yoghurt, stirrer machine

Submited : 30 Nopember 2016 Revision : 2 Desember 2016 Accepted : 21 Januari 2017 


\section{PENDAHULUAN}

Yogurt adalah bahan makanan yang terbuat dari susu yang difermentasikan oleh bakteri asam laktat. Yogurt mempunyai rasa yang unik yaitu mempunyai rasa asam dan memiliki khasiat bagi kesehatan.Bakteri yang terdapat di dalam yogurt yaitu Lactobacillus bulgaricus dan Streptococcus thermophilus. Bakteri tersebut memiliki kemampuan dalam memfermentasikan susu sehingga dimanfaatkan sebagai dasar dalam proses pembuatan yoghurt. Yoghurt sangat baik untuk kesehatan, terutama untuk menjaga keasaman lambung dan dapat menekan pertumbuhan bakteri patogen di usus. Kandungan gizi yang terdapat pada yoghurt lebih tinggi daripada susu sapi yaitu setiap $100 \mathrm{~g}$ yoghurt mengandung $55 \mathrm{kkl}$, protein $3.3 \mathrm{~g}$, lemak $2.5 \mathrm{~g}$, karbohidrat $4.0 \mathrm{~g}$, kalsium $120 \mathrm{mg}$, fosfor $90 \mathrm{mg}$ dan zat besi $0.1 \mathrm{mg}$ (Legowo, dkk., 2009).

Selain memiliki manfaat yang lengkap sebagai minuman kesehatan, yoghurt memiliki harga yang terjangkau dan telah banyak dikonsumsi oleh masyarakat.Oleh karena itu, banyak industri rumahan yang mulai tertarik untuk menjadikan yoghurt sebagai salah satu usaha alternatif untuk meningkatkan pendapatan dalam skala industri rumah tangga.Beberapa diantara UKM yang mengelola usaha rumahan yoghurt ini adalah UKM Yoghurt Yovita dan UKM Yoghurt Yosh yang bertempat di Kelurahan Bandungrejosari, Kecamatan Sukun, Malang.

Pemilik UKM Yoghurt Yovita ini adalah Bapak Muryat.Dalam pengelolaan usahanya, Bapak Muryat

dibantu oleh 6 karyawan.Setiap hari UKM ini memproduksi yoghurt lilin sebanyak 3500 buah, dan yoghurt cup sebanyak 75 buah.Produk yoghurt ini memiliki 3 reseller yang mengambil produk tersebut dan menjualnya lagi. Selain itu, produk yoghurt tersebut juga dijual di warung-warung serta ada 50 kantin dan toko yang bekerja sama menjualkan produk ini.

Sementara, pemilik UKM Yoghurt Yosh adalah Ibu Sumarsih dan dibantu oleh 3 karyawan.Setiap hari UKM ini memproduksi yoghurt lilin sebanyak 1000 buah dan yoghurt cup kecil sebanyak 50 buah.Produk yoghurt tersebut memiliki 3 reseller yang mengambil yoghurt tersebut untuk dijual kembali ke warung-warung dan sekolah-sekolah di daerah Malang.

Pemasaran dilakukan secara langsung dengan mendatangi tempat penjualan di warung, toko maupun sekolah tertentu saja dengan dibantu oleh reseller.Karena produk yoghurt ini banyak yang di titipkan di sekolah maupun warung-warung yang ada di dekat sekolah, sehingga penjualan dapat meningkat saat anak sekolah masuk, namun saat liburan sekolah produk yoghurt yang terjual hanya sedikit.

Proses pembuatan minuman
yoghurt ini terdiri dari tahap
pencampuran bahan dengan mixer,
pemberian rasa dan gula, serta
pengadukan. Tiga tahap ini harus
dilakukan secara simultan dan dalam
waktu pendek. Bahan dasar dari
pembuatan yoghurt ini adalah susu sapi
yang dimasak terlebih dahulu. Begitu
pula dengan gula yang digunakan harus


dicairkan terlebih dahulu sehingga mudah tercampur langsung dengan adonan. Pada proses pembuatan yoghurt ini, pekerja tidak dapat meninggalkan adonan yoghurt terlalu lama, mulai dari proses memasak susu sapi hingga pada penyimpanan di lemari pendingin. Apabila, salah tata cara dan tidak tepat waktu pengolahan maka dapat menyebabkan adonan yoghurt gagal untuk dibuat.

Selain itu, dalam pembuatan yoghurt ini, penggunaan mixer standart berukuran 3 liter pada tahap pencampuran bahan dirasa masih belum efisien.Terbatasnya kapasitas mixer yang digunakan menyebabkan pemilik usaha yoghurt tersebut harus memproduksi yoghurt secara berulang dan membutuhkan waktu yang relatih lebih lama serta menghabiskan tenaga. Dalam sehari, proses produksi yoghurt pada UKM Yovita dilakukan hingga 10-15 kali. Sedangkan pada UKM Yosh pembuatan yoghurt dilakukan hingga 6-10 kali.Dengan satu kali pembuatan menghasilkan sekitar 60-70 buah yoghurt lilin.Hal ini tentunya menyebabkan produk yoghurt yang dihasilkan kurang maksimal.Padahal usaha yang ditekuni Bapak Muryat dan Ibu Sumarsih ini telah memiliki banyak reseller untuk menjualkan kembali hasil produksi yoghurt tersebut di wilayah sekitar Malang dan sekitarnya. Oleh karena itu, apabila proses pembuatan ini dapat dipercepat dan tidak menguras tenaga serta diolah dalam kapasitas produksi yang lebih besar, maka produk yoghurt yang dihasilkan juga semakin banyak.

Usaha rumah tangga yoghurt ini dapat menjadi usaha yang memiliki prospek bagus bagi kedepannya. Selain itu, usaha ini juga berpengaruh besar terhadap faktor peningkatan perekonomian pada pelaku usaha rumah tangga tersebut, dikarenakan usaha ini dapat menghasilkan keuntungan yang besar melalui hasil produksi yang besar pula.

\section{METODE}

Kegiatan yang dilakukan untuk menyelesaikan permasalahan dapat dilihat pada gambar ini :

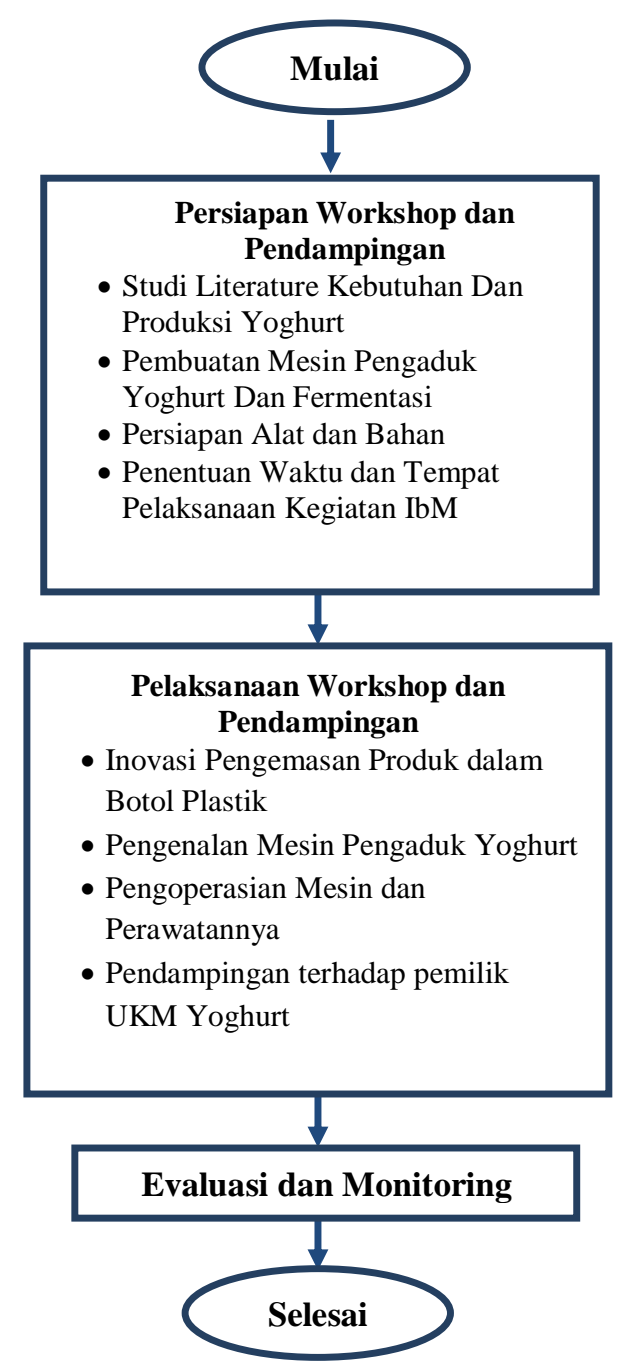

Gambar 1. Diagram Alir Pelaksanaan Kegiatan 
Dari diagram di atas dapat dijelaskan rencana kegiatan yang akan dilakukan antara lain sebagai berikut:

\section{Persiapan Worksop dan Pendampingan}

Tahap awal persiapan workshop dan pendampingan ini dimulai dengan studi literature kebutuhan dan produksi yoghurt, proses desain dan pembuatan mesin pengaduk yoghurt dan fermentasi. Mesin akan dibuat dengan kapasitas besar yaitu 30 liter/jam sebagai pengganti penggunaan mixer standar yang memiliki kapasitas sedikit. Mesin ini digerakkan dengan tenaga listrik dan sesuai dengan daya yang dimiliki UKM tersebut. Sehinga UKM tidak perlu melakukan peningkatan daya ke PLN. Dengan adanya proses produksi otomatis yang dilakukan maka diharapkan dapat meningkatkan kualitas maupun kuantitas produk yoghurt yang dihasilkan.

Langkah selanjutnya adalah mempersiapkan alat dan bahan-bahan yang akan digunakan pada saat workshop dan proses pendampingan. Yang tidak kalah pentingnya adalah komunikasi dengan mitra sebagai sasaran dari kegiatan ini dalam keikutsertaannya pada kegiatan workshop terutama dalam menentukan waktu dan tempat pelaksanaan workshop.

\section{Pelaksanaan Worksop dan Pendam- pingan}

Kegiatan workshop dan pendampingan dilakukan untuk melatih mitra dalam mengoperasikan mesin pengaduk yoghurt secara mandiri serta menunjukkan keunggulan penggunaan mesin pengaduk tersebut dalam pengolahan yoghurt jika dibandingkan dengan menggunakan mixer standart beserta perawatan dan trouble shooting.Selain itu, juga dilakukan workshop dan pendampingan dalam penambahan inovasi pengemasan serta distribusi dan pemasaran hasil produksi kepada mitra untuk memperluas peamsaran serta meningkatkan penjualan yoghurt UKM tersebut.Hal ini dilakukan agar volume produksi yang dilakukan mampu terserap sepenuhnya kepada masyarakat.Trainer yang akan mengisi kegiatan worksop dan pendampingan adalah dari Tim IbM yeng memiliki kompetensi sesuai kebutuhan mitra.

\section{Partisipasi dari UKM Yoghurt}

Dalam kegiatan ini seluruhnya melibatkan partisipasi dari mitra secara langsung. Kegiatan ini dimaksudkan untuk menanamkan rasa kepemilikan mitra dalam kegiatan ini, sehingga dengan model partisipasi penuh dari mitra akan mensukseskan kegiatan ini serta dapat membantu meningkatkan hasil produksi yoghurt. Dengan demikian diharapkan kedepannya dapat membantu mitra untuk menghasilkan omzet yang lebih besar secara berkelanjutan.

\section{Monitoring dan Evaluasi}

Tahap monitoring dan evaluasi dilakukan agar proses keberlanjutan oleh mitra yang tentunya masih membutuhkan pembimbingan dalam proses pelaksanaan program. Dengan demikian tujuan dari tahap ini adalah sebagai berikut : 
1. Melihat perkembangan program yang telah dilaksanakan.

2. Mengetahui kendala yang ada dalam proses pelaksanaan program.

3. Mencari solusi terhadap masalah yang ada.

Proses monitoring dan evaluasi ini akan dilakukan oleh Tim bersama mitra. Dengan demikian, kendala maupun kekurangan yang terjadi dalam pelaksanaan program dapat diperbaiki menjadi lebih baik sehingga program yang dilaksanakan benar-benar efektif dan maksimal serta bersinergis.

\section{HASIL DAN PEMBAHASAN}

\section{Hasil Kegiatan}

Kegiatan ini dilaksanakan dalam dua tahap yaitu kegiatan workshop dan pendampingan mitra.

\section{Kegiatan Workshop}

Kegiatan workshop pada mitra dilaksanakan salama tiga hari yaitu pada tanggal $21 \mathrm{~s} / \mathrm{d} 23$ Juni 2017, jam $16.00 \mathrm{~s} / \mathrm{d} 18.00$ WIB di kediaman Bapak Muryat dan Ibu Sumarsih. Urutan kegiatan workshorp antara lain adalah:

1. Pengenalan mesin pengaduk yoghurt oleh Tim pelaksana kegiatan.

2. Pemberian modul cara pengoperasian mesin.

3. Diskusi dan tanya jawab.

Kegiatan workshop ini diikuti oleh 6 orang yaitu: 2 pemilik UKM yaitu Bapak Muryat dan Ibu Hariyati beserta 2 karyawan pada masingmasing UKM tersebut. Selama kegiatan workshop berlangsung terlihat bahwa para peserta sangat antusias dalam mengikuti kegiatan ini.Hal ini terlihat dari respon peserta terutama pemilik UKM yang banyak berdiskusi dengan Tim pelaksana kegiatan saat kegiatan workshop dilak-sanakan.Bahkan mitra tidak sungkan untuk bertanya saat kurang memahami materi yang diberikan oleh Tim pelaksana kegiatan.Selain itu, mitra mengikuti kegiatan workshop ini dengan tertib dari awal hingga akhir kegiatan.

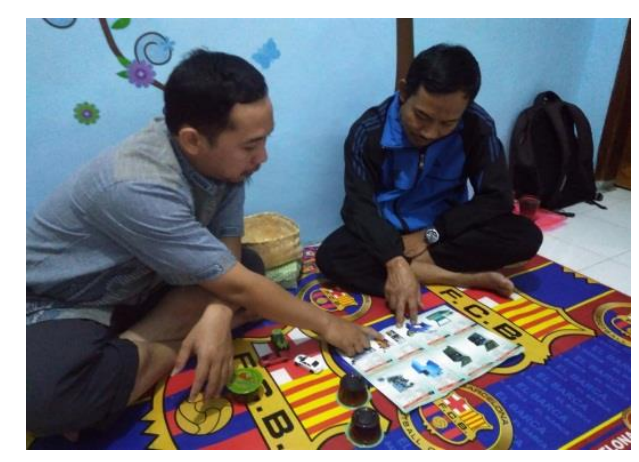

Gambar 2. Kegiatan Workshop bersama Bapak Muryat

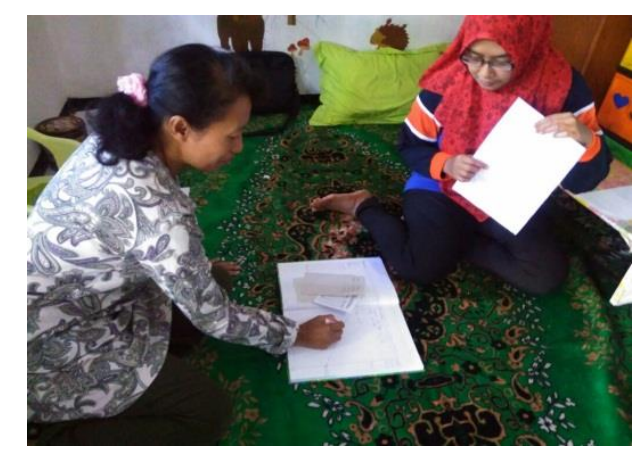

Gambar 3. Kegiatan Workshop bersama Ibu Sumarsih

Setelah kegiatan ini dilaksanakan kami melaksanakan evaluasi bersama pemilik UKM mengenai kegiatan workshop yang telah dilaksanakan. Berdasarkan hasil eva-luasi diperoleh keterangan bahwa para peserta telah memahami materi-materi yang disampaikan oleh tim pelaksana 
kegiatan, namun ada beberapa masalah yang perlu diselesaikan bersama, yaitu peserta belum dapat mengoperasikan mesin secara langsung karena pada saat kegiatan hanya diterangkan pada materi dan hanya belajar melalui modul saja.

Dari hasil evaluasi ini kegiatan dilanjutkan dengan kegiatan pendampingan terhadap mitra secara langsung dalam proses pengoperasian mesin.

\section{Kegiatan Pendampingan Mitra}

Kegiatan Pendampingan Mitra dilak-sanakan selama empat hari yaitu 20 s/d 23 Juni 2017, jam 16.00 s/d 18.00 di kediaman Bapak Muryat. kegiatan ini diikuti oleh 6 orang yaitu 2 pemilik UKM beserta 2 orang karyawan di masing-masing UKM tersebut. Urutan kegiatan pendampingan ini diberikan sebagai berikut:

1. Demo pengoperasian mesin pengaduk yoghurt oleh Tim pelaksana kegiatan.

2. Pengoperasian mesin pengaduk yoghurt oleh mitra secara mandiri dengan didampingi oleh Tim pelaksana kegiatan.

3. Diskusi dan tanya jawab.

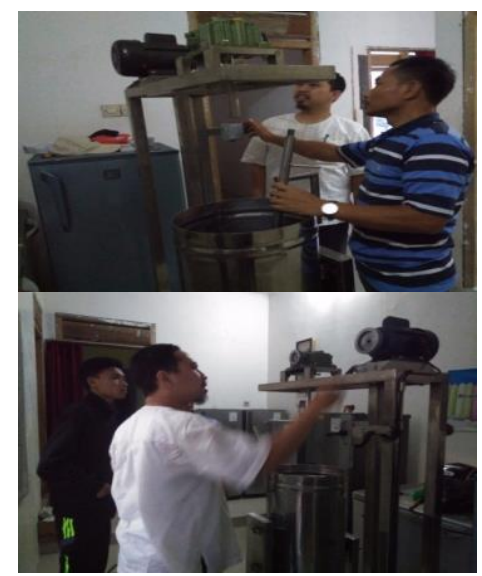

Gambar 4. Kegiatan Pendampingan Mitra
Pada kegiatan pendampingan ini, para peserta diminta oleh Tim pelaksana kegiatan mencoba secara langsung untuk mengope-rasikan mesin serta langkah-langkah pera-watan, perbaikan dasar serta trouble shotting mesin pengaduk yoghurt.Namun, ada beberapa peserta yang masih kesulitan menggunakan mesin pengaduk tersebut. Kemudian, salah satu dari tim menjelaskan kembali langkah-langkah disertai dengan demo pengoperasian mesin secara perlahan kepada peserta kegiatan ini. Setelah kegiatan pendampingan dilaksa-nakan, kegiatan dilanjutkan dengan evaluasi.Hasil evaluasi menunjukkan bahwa peserta kegiatan telah dapat mengoperasikan dan mencoba langkah-langkah perawatan mesin dengan baik.Pemilik UKM pun mengatakan bahwa para karyawannya merasa termudahkan dengan adanya mesin pengaduk yoghurt yang diberikan.

\section{Luaran yang Dicapai}

Luaran yang dicapai dari kegiatan ini antara lain adalah :

\section{Mesin Pengaduk Yoghurt Otomatis}

Mesin pengaduk yoghurt berfungsi untuk mengaduk adonan/bahan pembuat yoghurt yang disertai dengan timer sehingga pemilik UKM dapat mengatur waktu pengadukan sesuai dengan yang diinginkan. Mesin pengaduk yoghurt ini digunakan sebagai pengganti mixer standart pada proses produksi yoghurt. 


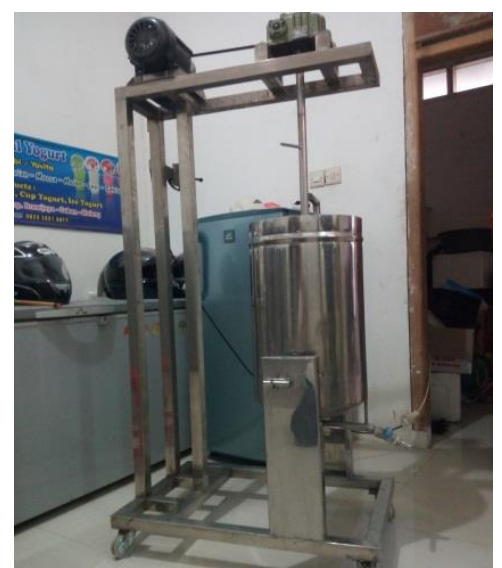

\section{Gambar 5. Mesin pengaduk Yoghurt} Otomatis

Mesin pengaduk yoghurt memiliki spesifikasi sebagai berikut:

1. Kapasitas $50 \mathrm{Kg} /$ Proses

2. Bahan Frame: Stainless Steel

3. Bahan Tabung: Stainless Steel

4. Dimensi Mesin: 84X70x182 Cm

5. Daya Listrik Max : $750 \mathrm{~W} / 220 \mathrm{~V}$

6. Transmisi Rpm: 20 \&Ndash; 40 Rpm

Sementara, komponen-komponen pada mesin pengaduk yoghurt diberikan sebagai berikut :

1. Kerangka : berfungsi sebagai penopang semua komponen mesin.

2. Motor Listrik :berfungsi sebagai unit penggerak dalam operasi mesin.

3. Poros Motor :berfungsi sebagai dudukan pulley juga sebagai penerus gaya dari motor listrik diteruskan ke pulley.

4. Bearing :berfungsi sebagai dudukan poros dan agar poros tidak mengalami aus.

5. Pulley Penggerak :berfungsi sebagai penerima putaran dari poros dan sebagai dudukan $V$-belt.

6. V-Belt: berfungsi sebagai pemindah putaran, dari pulley penggerak dipindahkan putarannya ke pulley pengaduk.
7. Poros Pengaduk :berfungsi sebagai tempat dudukan pulley pengaduk dan juga sebagai penghubung putaran yang diterima pulley pengaduk untuk diteruskan ke pengaduk.

8. Pengaduk :berfungsi untuk mengaduk bahan baku sabun mandi cair didalam.

9. Wadah pengadukan : berfungsi sebagai tempat bercampurnya bahan baku yang diaduk (Misbah dan Sakti, 2013).

10. Timer : berfungsi mengatur lamanya proses pengadukan.

dari $\begin{gathered}\text { Cara kerja dari mesin ini dimulai } \\ \text { pemutaran timer untuk }\end{gathered}$ menentukan waktu pengadukan yang diinginkan. Setelah itu, motor listrik bergerak untuk memutar poros dan menggerakkan pulley berdiameter kecil, kemudian diteruskan ke diameter pulley yang besar dengan $V$ - belt. Selanjutnya pengaduk akan berputar mengikuti putaran pulley untuk mengaduk bahan pembuatan yoghurt. Setelah timer berhenti berputar, maka proses pengadukan akan berhenti secara otomatis.

Keunggulan dari mesin pengaduk yoghurt antara lain:

1. Adanya kapasitas wadah tempat pengadukan yang besar sehingga dapat mempercepat waktu pengadukan serta mengahasilkan produk yang lebih banyak daripada menggunakan mesin standart.

2. Hasil adukan lebih halus dan merata

3. Sistem pengadukan otomatis dengan menggunakan timer, sehingga dapat menghemat tenaga. 
Melalui mesin pengaduk yoghurt yang telah dibuat oleh tim pelaksana kegiatan ini, mitra dapat meningkatkan hasil produksi yoghurtnya.

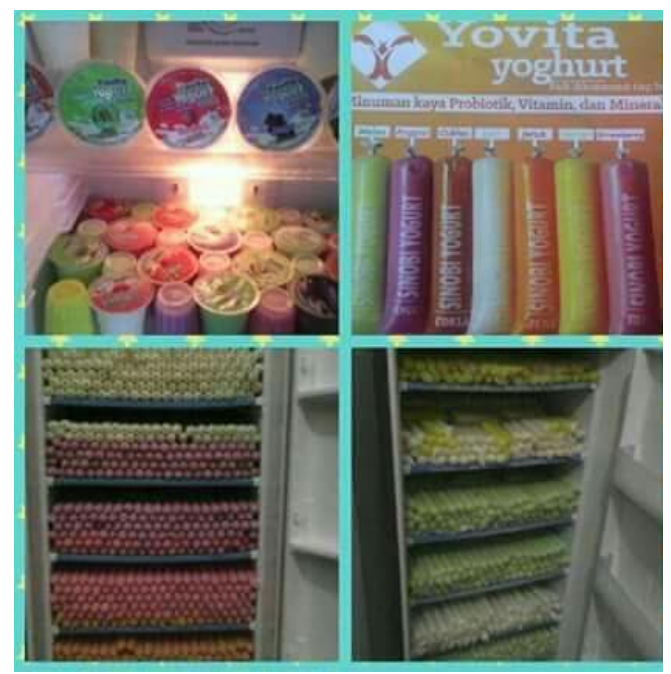

Gambar 6. Produksi Yoghut

\section{SIMPULAN}

Berdasarkan kegiatan yang telah dilaksanakan di atas, dapat diambil kesimpulan antara lain :

1. Program pengabdian pada UKM Yoghurt mengenai penyelesaian dalam proses produksi telah dilaksanakan dengan baik dan lancar.

2. Mesin pengaduk yoghurt yang dibuat pada program ini telah membantu memudahkan kerja karyawan dari kedua UKM yoghurt tersebut. Selain dapat menghemat waktu, penggunaan mesin ini juga tidak banyak menguras tenaga.

Dengan adanya mesin pengaduk tersebut telah membantu mitra dalam mening-katkan produk yoghurt yang dihasilkan

\section{DAFTAR PUSTAKA}

Legowo, A. M., S. Mulyani dan Kusrahayu. (2009). Teknologi Pengolahan Susu. Semarang : Universitas Diponegoro.

\author{
Misbach, M. dan A. M. Sakti. 2013. \\ Rancang Bangun Mesin \\ Pengaduk Bahan Baku Sabun \\ Mandi Cair. JRM. 01(02): 28- \\ 34.
}

